\title{
Review: Feed demand landscape and implications of food-not feed strategy for food security and climate change
}

\author{
H. P. S. Makkar ${ }^{\dagger}$ \\ Food and Agriculture Organization of the United Nations (FAO), Animal Production and Health Division, Rome 00153, Italy
}

(Received 3 March 2017; Accepted 11 August 2017; First published online 4 December 2017)

The food-feed competition is one of the complex challenges, and so are the ongoing climate change, land degradation and water shortage for realizing sustainable food production systems. By 2050 the global demand for animal products is projected to increase by $60 \%$ to $70 \%$, and developing countries will have a lion's share in this increase. Currently, 800 million tonnes of cereals (one-third of total cereal production) are used in animal feed and by 2050 it is projected to be over 1.1 billion tonnes. Most of the increase in feed demand will be in developing countries, which already face many food security challenges. Additional feed required for the projected increased demand of animal products, if met through food grains, will further exacerbate the food insecurity in these countries. Furthermore, globally, the production, processing and transport of feed account for $45 \%$ of the greenhouse gas emissions from the livestock sector. This paper presents approaches for addressing these challenges in quest for making livestock sector more sustainable. The use of novel human-inedible feed resources such as insect meals, leaf meals, protein isolates, single cell protein produced using waste streams, protein hydrolysates, spineless cactus, algae, co-products of the biofuel industry, food wastes among others, has enormous prospects. Efficient use of grasslands also offers possibilities for increasing carbon sequestration, land reclamation and livestock productivity. Opportunities also exist for decreasing feed wastages by simple and well proven practices such as use of appropriate troughs, increase in efficiency of harvesting crop residues and their conversion to complete feeds especially in the form of densified feed blocks or pellets, feeding as per the nutrient requirements, among others. Available evidence have been presented to substantiate arguments that: (a) for successful and sustained adoption of a feed technology, participation of the private sector and a sound business plan are required, (b) for sustainability of the livestock production systems, it is also important to consider the consumption of animal products and a case has been presented to assess future needs of animal source foods based on their requirements for healthy living, (c) for dairy animals, calculation of Emission Intensity based on the lifetime lactation rather than one lactation may also be considered and (d) for assessment of the efficiency of livestock production systems a holistic approach is required that takes into consideration social dimensions and net humanedible protein output from the system in addition to carbon and water footprints.

Keywords: human-inedible, novel feed, food security, animal product consumption, climate change

\section{Implications}

Feed production and use is highly resource demanding. Ongoing food-feed competition, land degradation and climate change presents significant sustainability challenges to livestock industry, especially against the backdrop of increasing feed demand, resulting from increased animal source food consumption. A synthesis presented in this publication on the use of novel human-inedible feed resources, application of smart feeding strategies coupled with participation of the private sector, use of a holistic approach that includes social parameters in assessing the efficiency of a production system along with net human-edible protein output, and bringing

\footnotetext{
${ }^{\dagger}$ E-mail: hpsmakkar@outlook.com
}

animal product consumption into the sustainability discussion would increase food security and reduced environment damage from livestock production systems. This will also give impetus to the use of human-inedible plant and sea resources as livestock feed.

\section{Introduction}

The feed is the main driver of livestock production while animal reproduction and breeding, and animal health and welfare, play supporting albeit important roles. Feed accounts for up to $70 \%$ of the total cost of livestock operation. The safety and quality of the food chain can be affected because of the close link between feed and foodborne 
pathogens. Feeding of poor or unbalanced feed adversely affects the production, health and welfare of animals. Besides, this also diverts a substantial portion of feed nutrients to wasteful products in the form of greenhouse gases (GHG). Globally, the production, processing and transport of feed account for $45 \%$ of the GHG emissions from the livestock sector, and contribution of enteric methane is 39\% (Gerber et al., 2013), which also depends on the type of feed fed to livestock. The area dedicated to feed-crop production represents $33 \%$ of total arable land and the grazing land constitutes $30 \%$ of the terrestrial land. Livestock use $8 \%$ of global human water use. Over $90 \%$ of the water use in the livestock sector is for irrigation of feed crops (Food and Agricultural Organization, 2009). Evidently, the resource demand for feed production is very high.

\section{Feed demand landscape}

Industrialized production accounts for $55 \%$ and $71 \%$ of global pork and poultry production, respectively. By 2050 the global demands for dairy products and meat are projected to increase by $74 \%$ and $58 \%$, respectively, and a large part of this demand will originate from developing countries (Food and Agricultural Organization (FAO), 2012a). Currently, $\sim 800$ million tonnes of cereals (one-third of total cereal production) are used in animal feed and by 2050 it is projected to be over 1.1 billion tonnes. As a result of the expansion of monogastric sector, the demand for maize and coarse grains in 2050 is projected to constitute nearly half of the grain produced. In $2000,78 \%$ of feed grains were fed to pigs and poultry in regions where industrial intensive system dominate (Herrero et al., 2013). In 2013 the monogastric sector consumed 155 million tonnes of feed protein and in 2030 an additional 52 million tonnes of feed protein would be required to meet this sector's demand. Almost $90 \%$ of this additional requirement is likely to originate from developing countries, which already face many food security challenges (Makkar, 2016). A large part of this additional protein will compete with human food. This leads to considerable tradeoffs with producing food for direct human consumption as food provision via animals entails large conversion losses. The proportion of arable land used for livestock feed production is expected to increase further, thus increasing the pressure on arable land areas (Alexandratos and Bruinsma, 2012). China's role in the feed grain trade and use has been significant. Currently China produces half of the world's pork, $20 \%$ of the world's poultry and $10 \%$ of the world's beef. It is the world's largest soybean (for animal feed) importer (60 million tonnes). China is also importing dried distillers grains, and grains such as barley, wheat and sorghum for feed from several countries. In 2011, China used $\sim 70 \%$ of its total corn production for feed. The total global trade in corn is much less than China's entire corn feed demand. In the future, feed ingredient demand in China will further increase due to further increase in consumption of animal products. This increase in demand for feed ingredients would have vast implications for world trade, land-use change and price of feed ingredients and on the environment. Another growing economy, India would require a substantial amount of feed for its monogastric sector. Chicken accounts for most of poultry meat in India, and it has been estimated that $\sim 27$ million tonnes of additional feed would be required per year by 2030 compared with 2000 by the Indian broiler industry (Robinson and Makkar, 2012).

The food-feed competition (foods especially grains used as animal feed) is one of the complex challenges, and so are the ongoing climate change, land degradation and water shortages that need addressing for sustainable intensification of livestock production and for realization of sustainable food production and consumption systems. In addition to grain use for feeding livestock, $\sim 6 \%$ of the grains produced are used for bioethanol production (Food and Agricultural Organization (FAO), 2012b). Currently, there is a huge shortage of feeds of good quality in developing countries. Additional feed required for the projected increased demand of animal products, if met through food grains, will further exacerbate the food insecurity in these countries. Livestock use about $60 \%$ of the biomass used for food production. Ruminant livestock consume $78 \%$ of this biomass used and convert crop residues and by-products into edible products. Furthermore, in marginal areas, where agro-ecological conditions and weak infrastructures do not offer much alternative, it is the main source of livelihoods and food. Most of the dry matter consumed by livestock is composed of grass $(39 \%)$ and other non-humanly edible materials such as crop residues $(26 \%)$ and agricultural by-products ( $8 \%)$. Modest improvements in feed conversion efficiency can prevent further expansion of arable land dedicated to feed production (Mottet et al., 2017). Technologies are available that enhance feed conversion efficiency of crop residues and byproducts. Given that feed is by far the dominating physical flow in the food production systems, in energy terms, increase in feed conversion efficiency enhances overall resource-use efficiency. Use of food-not feed resources (human-inedible resources), including novel feed resources that do not compete with human food and forages from grazing land, and revisiting some of the proven crop-based technologies and their implementation following business models would help address these feed related challenges.

\section{Food-not feed resources}

Insect meals, co-products of the biofuel industry, seaweeds, protein isolates, leaf meals, single cell proteins, protein hydrolysates and slaughterhouse and food wastes have potential to replace human-edible components in the diets of food producing animals. In this section emphasis has been given on incorporation of these resources in monogastric diets because of high use of cereals in them; however, these can be used in the diets of ruminant livestock.

Insect meal

Black soldier (Hermetia illucens) larvae meal, housefly maggots (Musca domestica), meal worm (Tenebrio molitor) and 
Table 1 Amino acid composition of some insect meals ( $g / 16 \mathrm{~g} \mathrm{~N}$ )

\begin{tabular}{lcccc}
\hline \hline Amino soldier acids & Black fly & Housefly maggot meal & Meal worm & Silkworm pupae meal (defatted) \\
\hline Alanine & $7.7 \pm 0.8$ & $5.8 \pm 1.0$ & $7.3 \pm 1.0$ & $4.4 \pm 0.2$ \\
Arginine & $5.6 \pm 0.3$ & $4.6 \pm 0.7$ & $4.8 \pm 1.0$ & $5.1 \pm 0.3$ \\
Aspartic acid & $11.0 \pm 1.8$ & $7.5 \pm 1.5$ & $7.5 \pm 1.7$ & $7.8 \pm 0.7$ \\
Cystine & 0.1 & $0.7 \pm 0.2$ & $0.8 \pm 0.0$ & $0.8 \pm 0.5$ \\
Methionine & $2.1 \pm 0.3$ & $2.2 \pm 0.8$ & $1.5 \pm 0.4$ & $3.0 \pm 0.4$ \\
Lysine & $6.6 \pm 0.9$ & $6.1 \pm 0.9$ & $5.4 \pm 0.8$ & $6.1 \pm 0.4$ \\
Isoleucine & $5.1 \pm 0.5$ & $3.2 \pm 0.5$ & $4.6 \pm 0.5$ & $3.9 \pm 0.2$ \\
Leucine & $7.9 \pm 0.6$ & $5.4 \pm 0.6$ & $8.6 \pm 1.8$ & $5.8 \pm 0.2$ \\
Phenylalanine & $5.2 \pm 0.4$ & $4.6 \pm 0.8$ & $4.0 \pm 0.4$ & $4.4 \pm 0.3$ \\
Threonine & $3.7 \pm 1.7$ & $3.5 \pm 07$ & $4.0 \pm 0.5$ & $4.8 \pm 0.3$ \\
Tryptophan & 0.5 & $1.5(1.4,1.5)$ & $0.6 \pm 0.5$ & $1.4 \pm 0.2$ \\
Glutamic acid & $10.9 \pm 2.4$ & $11.7 \pm 1.8$ & $11.3 \pm 1.1$ & $8.3 \pm 0.7$ \\
Histidine & $3.0 \pm 1.0$ & $2.4 \pm 0.8$ & $3.4 \pm 0.2$ & $2.6 \pm 0.1$ \\
Proline & $6.6(5.5,7.7)$ & $3.3 \pm 0.7$ & $6.8 \pm 0.2$ & $5.2(4.0,6.5)$ \\
Serine & $3.1 \pm 1.9$ & $3.6 \pm 0.5$ & $7.0 \pm 3.5$ & $4.5 \pm 0.2$ \\
Tyrosine & $6.9 \pm 0.7$ & $4.7 \pm 1.4$ & $7.4 \pm 0.3$ & $5.5 \pm 0.2$ \\
Valine & $8.2 \pm 1.4$ & $4.0 \pm 1.1$ & $6.0 \pm 0.6$ & $4.9 \pm 0.2$ \\
\hline \hline
\end{tabular}

Values are mean \pm SD. When $n=2$, individual values are given.

Source: Makkar et al. (2014).

silkworm (Bombyx mori) pupae meal have been widely studied for use as animal feed.

Black soldier larvae meal contains about $40 \%$ CP. This insect meal was found to be a suitable ingredient in growing pig, poultry and fish diets. Among various insect meals, average lysine content is highest in Black soldier lavae (Table 1). However, its relative deficiency in sulphurcontaining amino acids and threonine (Table 1) requires the inclusion of these amino acids. Dried black soldier fly prepupae meal was fed to early weaned pigs: without amino acid supplementation, the $50 \%$ replacement diet gave slightly better performance during phase 1 ( $+4 \%$ gain, $+9 \%$ feed efficiency); however, the $100 \%$ replacement diets did not perform as well as the control. Additional refinement (cuticle removal and rendering) may be necessary to make the meal suitable for early weaned pigs. As a component of a complete diet, black soldier fly larvae meal has been found to support good growth in chicks. Chicks fed a diet containing dried black soldier fly larvae (as a substitute for soymeal) gained weight at the same rate as chicks fed the control diet containing soymeal. This meal could partially or fully substitute for fishmeal in fish diets (Makkar et al., 2014; Tran et al., 2015).

Housefly maggots are a source of protein and lipids. Older larvae contain less CP and more lipids. Phosphorous contents in housefly maggots are of similar order as in black soldier fly larvae, but $\mathrm{Ca}$ levels are lower by about 15 times. The level of lysine in Maggot meal is comparable with that in soymeal (Tables 1 and 2). Mealworms contain high amounts of CP and fat. They are relatively low in ash and like other insects they have a low Ca content and a very low Ca:P ratio.

Sows and their offspring fed a diet containing processed housefly maggot meal did not show any adverse effects on pigs (Makkar et al., 2014). Successful incorporation of this meal, as replacement for soymeal and fishmeal, in poultry and fish diets has been demonstrated. There is limited
Table 2 Amino acid composition of Moringa oleifera leaves, soymeal and fishmeal $(g / 16 \mathrm{gN})$

\begin{tabular}{lccc}
\hline \hline Amino acids & Moringa & Soymeal & Fishmeal \\
\hline Lysine & 5.6 & 6.18 & 7.50 \\
Leucine & 8.70 & 7.58 & 7.20 \\
Isoleucine & 4.50 & 4.16 & 4.20 \\
Methionine & 1.98 & 1.32 & 2.70 \\
Cystine & 1.35 & 1.38 & 0.80 \\
Phenylalanine & 6.18 & 5.16 & 3.90 \\
Tyrosine & 3.87 & 3.35 & 3.10 \\
Valine & 5.68 & 4.50 & 4.90 \\
Histidine & 2.99 & 3.06 & 2.40 \\
Threonine & 4.66 & 3.78 & 4.10 \\
Serine & 4.12 & 5.18 & 3.90 \\
Glutamic Acid & 10.22 & 19.92 & 12.60 \\
Aspartic Acid & 8.83 & 14.14 & 9.10 \\
Proline & 5.43 & 5.99 & 4.20 \\
Glycine & 5.47 & 4.52 & 6.40 \\
Alanine & 7.32 & 4.54 & 6.30 \\
Arginine & 6.23 & 7.64 & 6.20 \\
Tryptophan & 2.10 & 1.36 & 1.00 \\
\hline \hline
\end{tabular}

Sources: Makkar and Becker (1997) and Makkar et al. (2014).

information on the use of mealworms in the diets of pigs (Makkar et al., 2014). Meal worm can also be used in the diets of various fish species at $25 \%$ to $50 \%$ protein substitution levels (Tran et al., 2015).

Silkworm (B. morl) has high CP, low Ca and low Ca:P ratio. The essential amino acids are particularly high (Table 1). Silkworm meal could fully replace fishmeal in the diet of growing and finishing pigs without altering carcass and meat quality and blood parameters (Medhi, 2011).

Studies conducted on various insect meals suggest that they could replace at least $50 \%$ of soymeal protein in the diets of pigs (Table 3 ) as well as other domestic animals, 
Table 3 Suggested levels of incorporation of biofuel co-products and other unconventional feed resources in livestock and fish diets

\begin{tabular}{ll}
\hline \hline Feed resources & Suggested levels \\
\hline Insect meal & Pig, poultry and fish: up to $50 \%$ replacement of protein from the conventional sources \\
Dried distillers grains with solubles & Growing pigs ( 2 to 3 weeks after weaning): up to $30 \%$ \\
& Finishing pigs: up $30 \%$ \\
& Gestating sows: up to $50 \%$ (as long as amino acid requirement is met) \\
& Laying hens: up to $30 \%$ \\
& Broilers: up to $10 \%$ \\
& Pre-weaned calves: up to $25 \%$ \\
& Growing heifers: up to $30 \%$ \\
& Dry cows: up to $15 \%$ \\
& Lactating dairy cows: up to $20 \%$ \\
& Pre-starting piglets $(6$ to $15 \mathrm{~kg}$ ): $12 \%$ \\
Glycerine & Nursery pigs: up to $18 \%$ \\
& Sows: up to $9 \%$ \\
& Fish and poultry: not much studied \\
Camelina sativa meal & Laying hens: up to $10 \%$ \\
Camelina sativa expeller cake & Pigs: up to $30 \%$, depending on the levels of glucosinolates \\
Brassica juncea cake & Pigs: up to $18 \%$ \\
Detoxified Jatropha curcas kernel meal & Pigs and fish: up to $50 \%$ replacement of protein from the conventional sources \\
Jatropha kernel meals from non-toxic genotype & Fish: up to $50 \%$ replacement of protein from the conventional sources \\
Palm kernel cake & Pigs: $20 \%$ to $25 \%$ of the diet \\
& Growing beef cattle: $30 \%$ to $80 \%$ \\
& Goats: $20 \%$ to $50 \%$ \\
Lactating dairy cattle: $20 \%$ to $50 \%$ \\
Poultry and freshwater fish: $<10 \%$
\end{tabular}

The levels of incorporation could be enhanced by taking steps to mitigate the effects of discriminatory factors present, and by addition of synthetic amino acids to meet the deficiency of essential amino acids; for other feed resources discussed in this section, little information is available to suggest the levels.

including poultry and fish (Makkar et al., 2014; Tran et al., 2015). More in-depth studies are required to optimize their level of inclusion, and, at high levels of inclusion, to also optimize the levels of supplementation of deficient amino acids. Studies on economic analysis of using insect meals are also suggested. Now that the EU has accorded permission to use insects in aquafeeds as of July 2017, greater investments in the production of insect meal as livestock feed is expected.

\section{Biofuel co-products}

Distiller grains, glycerin, fatty acid distillates and meals of Camelina, Brassica and jatropha are some of the novel feed resources under this category. As mentioned above, $\sim 6 \%$ of the grains are diverted for biofuel production, and stoichiometrically one-third, that is $2 \%$ of the grains are recovered as protein-rich feed resource in the form of distrillers grains. This ingredient also has considerable amount of energy left after conversion of starch into bioethanol (Makkar, 2014). In the last decade, incorporation of dried distillers grains with solubles (DDGS) in the diets of beef and pigs has substantially decreased human-edible components (maize and soya beans) (FAO, 2012b). The use of DDGS as a substitute for corn and soya bean in the diets of cattle, pigs, poultry and fish has been recorded. Dried distillers grains with solubles or with added protein can be fed to pigs and poultry (Table 3 ) (Makkar, 2014).

The undesirable factors present in DDGS could be mycotoxins, non-starch polysaccharides, phytate and antibiotics.
Swiatkiewicz et al. (2016) concluded that addition of nonstarch polysaccharide degrading enzymes is more effective than with adding phytases in the diets, in enhancing nutrient digestibilites and growth performance in animals.

Glycerin and fatty acid distillate are co-products of biodiesel industry and are good sources of energy and can replace cereals in livestock diets. Stoichiometrically $\sim 10 \%$ of oil used for biodiesel production is recovered as glycerin (Makkar, 2014), which also helps to decrease food-feed competition, resulting from oil use for biodiesel production. Neutralized semi-purified glycerin can be added into the diet of growing and finishing pigs (Gallego et al. 2016). Inclusion of glycerin at $18 \%$ to the nursery pig diet did not affect nutrient digestibility or plasma metabolites (Oliveira et al., 2014). Pigs can utilize fatty acids released from the distillate.

Other emerging co-products of the biodiesel production are the meals of Camelina and Brassica species, palm and jatropha (Makkar, 2014).Their suggested levels of incorporation are presented in Table 3.

\section{Seaweeds}

Seaweeds could be good sources of protein and minerals. Brown algae are of lesser nutritional value than red and green algae, due to their lower CP content. These algae contain polysaccharides, which when consumed in large amounts may cause adverse effects in pigs and poultry but the addition of enzyme cocktails might help. The use in ruminant diets might require adaptation period before these 
could be efficiently used (Makkar et al., 2016). Some seaweeds also have potential to decrease enteric methane emission (Dubois et al., 2013; Li et al., 2016).

Brown algae contain alginates, sulphated fucosecontaining polymers and laminarin; red algae contain agars, carrageenans, xylans, sulphated galactans and porphyrans; and green algae contain xylans and sulphated galactans. These macromolecules in small amounts have potential to be used as prebiotic for enhancing production and health status of both monogastric and ruminant livestock (McDonnell et al., 2010; Makkar et al., 2016). Work on these lines should be strengthened because of their high potential for increasing animal productivity.

\section{Protein isolates}

Protein isolates prepared from protein-rich plant materials such as white clover, rapeseed meal/cake, sunflower meal/ cake, palm oil cake, etc., could also be good substitutes for soymeal in monogastric diets. The process of protein isolate preparation reduces the content of fibre and antinutrients in the original materials, making them suitable for incorporation into the diets of poultry and swine. There is a need to explore the use of protein isolates prepared from these traditional ruminant feeds (Jankowski et al., 2009).

\section{Protein hydrolysates}

Proteases-aided aqueous extraction of oil from oil seeds is an attractive process because it does not use organic solvents and is classified as a green chemistry approach. These enzymes also convert proteins to protein hydrolysate, which is a good source of amino acids in animal diets (Latif et al., 2015). Strong move towards use of green chemistry in the future, such as the use of enzyme-added oil extraction, would enhance availability of hydrolyzed proteins for monogastrics. Other protein hydrolysates, for example from salmon proteins can be used in place of soya protein in the diets of weanling pigs (Opheim et al., 2016).

\section{Single cell proteins}

Single cell proteins $(\mathrm{SCP})$ obtained on growing bacteria, fungi, algae and yeasts especially on waste streams could also be exploited as feeds. Agro-industrial by-products rich in starch and sugars such as pineapple waste, cassava peal and culled tomatoes, after their enrichment with urea, could be converted into protein-rich products for use in monogastric diets (Rahman et al., 2016). Single cell proteins such as Prosin and Protide, SCP have been shown to replace $50 \%$ of fishmeal in the diet of weaned pigs (Zhang et al., 2013).

\section{Leaf meals}

Moringa oleifera is a very fast growing plant. Moringa if grown as a fodder plant, contains on an average $16 \%$ to $17 \% \mathrm{CP}$, whereas the leaf meal contains $25 \%$ to $27 \% \mathrm{CP}$. Its essential amino acid composition is very good and protein digestibility is very high (Table 3). Under intensive cultivation conditions, moringa protein yield per hectare could be almost five-times higher than that of soybean. It could be a good replacer of soymeal in monogastric diets, whereas the twigs and soft stems could be fed to ruminants. Moringa leaves are also rich in sugar, vitamin and antioxidants (Foidl et al., 2001), which may also increase meat quality.

Mulberry (Morus alba) leaf meal also has high protein content and good essential amino acid composition. Mulberry leaf meal, added to the diets of growing and fattening pigs at $20 \%$ level, successfully replaced the conventional protein sources, and decreased the feeding cost (Osorto et al., 2007).

Innovative feeding strategies need to be developed using these unconventional, high quality tree foliage meals in monogastric diets.

\section{Food waste as feed}

Food wastes should also be directed towards animal feeds rather than other purposes such as composting or burning. Vegetable wastes might limit performance of mongastric due to high levels of fibre present; however, fruit wastes can form a valuable ingredient in their diets (Wadhwa et al., 2015). Safety of these products must be ensured and future work to promote 'Waste to Wealth' strategy needs to be encouraged (Thieme and Makkar, 2017). It will not only enhance revenues but also avoid costs associated with disposal and pollution.

\section{Slaughterhouse wastes}

Non-utilization of slaughterhouse wastes, besides being a source of pollution, may create major aesthetic and catastrophic health concerns. Development and upscaling of efficient thermal, chemical and/or enzymatic techniques for their safe conversion into animal feed should be the focus area for the future. However, traditions, culture and religion are often important when slaughterhouse wastes are utilized for feed. Regulatory requirements are also important because many countries restrict their use as animal feed for reasons of animal and human health concerns.

\section{Spineless cactus}

Cultivation of spineless cactus (Opuntia ficus-indica) in degraded and marginal lands produces feed in water deficient conditions and also offers possibilities for carbon sequestration and land reclamation. A diet containing 60\% cactus pods can support a cow yielding $25 \mathrm{I}$ milk/day (Dubeux et al., 2015). In Tunisia, a study shows that lambs fed on straw supplemented with cactus and saltbush grew at the rate of $80 \mathrm{~g} /$ day (Makkar, 2016).

\section{Spill-over effects of the second generation biofuel}

Extensive research is underway on development of enzymes and treatments to enhance the economic viability and efficiency of the second generation biofuel production (Bansal et al., 2011; Vancov and McIntosh, 2011). These improved enzymes and treatments could possibly be used for obtaining feeds rich in simple-carbohydrates from grasses, straws, stovers and domestic wastes for feeding to 
monogatric, leading to reduction of human-edible components in diets.

\section{Revisiting proven food-not feed technologies}

Technologies dealt in this section have been promoted in the past, but they did not generate much impact at the farmers' level. These need revisiting in the changed scenario and appreciating that the private sector participation contributes to increased applicability and sustainability of technologies. The technologies discussed here are those that directly enhance nutrient supply from them by optimizing the rumen function.

Urea molasses multi-nutrient blocks. Urea molasses multinutrient blocks supplementation enhances supply of nutrients to rumen microbes which increases the nutrient supply to the ruminants from fibrous feedstuffs, thus enhancing their efficiency of utilization and profitability. The blocks also provide supplements to grazing animal in ranches, which is vital during the dry season when the quality of the forage in rangelands decreases. These blocks could also be used as a carrier for anthelminthic and tannin-neutralizing agents (Makkar, 2016).

Urea-ammoniation or $\mathrm{CaO}$ treatment of straw. Treatment of straws with urea increases digestibility by $10 \%$ to $15 \%$ units (Food and Agricultural Organization (FAO), 2011a). This leads to higher productivity and profitability. Instead of urea, calcium oxide treatment can also be used to treat straws and stovers (Shreck et al., 2012).

Densified straw-based total mixed rations. Technologies are available for collection of straws from the crop fields. The collected straws can be used to form total mixed ration (TMR) by mixing with locally available oil seed cakes, followed by compacting to form blocks or pellets. Such TMRs do not contain human-edible components and can maintain a cow giving up to $15 \mathrm{I}$ of milk/day. Also their use decreases feeding time. These blocks are easier and safer to transport and store. This technology can also be effective in disaster management and emergency situations (Food and Agricultural Organization (FAO), 2012c).

Development of a business model around a feeding technology. In 2011, through an e-conference, we investigated reasons for (non)adoption of the above-mentioned technologies despite great efforts of development organizations in promoting them (FAO, 2011a). In fact, silage and fodder production could also be considered among this set of technologies. Use of these technology was abandoned soon after the project concluded. The reasons for this were identified as: unavailability of the inputs or their availability at high costs, and preparation of feeds not fitting into the farmers' routine or taking a lot of time. However, at places where a private organization was involved, for example in preparing the blocks, straw-ammoniation or silage making, the technologies were being used even after the project had terminated. The private organizations were buying the inputs in bulk which provided them price negotiating power. Also the private organizations had better skills and equipment to produce the feeds in large amounts and of better quality at a lower cost.

Lessons learnt from the above are that for a successful adoption of a feed technology, there is a need to develop a business model around the technology and bring on board a private company. This will create jobs, promote businesses, enhance farmers' profit and bring social benefits in addition to enhancing efficiency of utilization of these food-not feed resources.

\section{Feeding strategies and food security and climate change}

\section{Novel feed resources}

Change and innovation is required in many livestock production systems. A concept of sustainable animal diets (StAnD) developed by FAO integrates the importance of efficient use of natural resources, protection of the environment, socio-cultural benefits, profitability (the 3-P dimensions) and ethical integrity and sensitivity (Makkar and Ankers, 2014). Furthermore, at a time when over one billion people are hungry and suitable land for growing crops is becoming increasingly scarce, the use of food-grade grains in the animal diets is certain to face increased questioning on both resource-use efficiency and ethical grounds. The need is to prepare a diet by selecting ingredients that meets the sustainability criteria and moves the livestock production system towards positive direction of change (Makkar and Ankers, 2014). The novel feed resources presented in this paper do not compete with human food, and meet one of the important elements of the StAnD, which targets reduction in the extent of human-edible components in animal diets. Their incorporation in the diets containing crop residues will also enhance nutrient availability from crop residues. Also most of the novel feeds discussed are either co-products or are produced by using agro-industrial by-products; therefore, the animal-sourced food produced using diets containing these ingredients are expected to have low carbon and water footprints and low land requirement.

\section{Precision feeding}

For ruminant production, one of the main aims of precision or balanced feeding is to maintain a healthy rumen and maximize microbial protein synthesis, which is vital for maximizing feed-use efficiency. At high levels of production, precision or balanced feeding should also provide the required supply (after taking into account the rumen supply from microbial protein synthesis) of rumen undegradable protein, amino acids and fat. These approaches increase productivity in conjunction with decrease in emissions of environmental pollutants (e.g. N, P and methane) when expressed per unit of animal product, and increase profitability of animal production and make the environment 
greener and friendly. Matching nutrients in the feed with those required by the animal results in marked decrease in excretions and negative environmental impacts (Carter and Kim, 2013).

Data generated so far show that feeding a balanced ration can increase net daily income by $10 \%$ to $15 \%$ for those having one to two cows and/or buffaloes. Furthermore, feeding balanced rations reduced enteric methane emissions, faecal egg counts of internal parasites and improved animal immunity (FAO, 2012a). Increase in feed-use efficiency has environment, economic, social and animal welfare benefits (Bindari and Makkar 2016).

\section{Smart feeding options}

The aim in developing countries should be to practice 'smart balanced feeding' to meet the physiological needs of animals. An example of 'smart feeding' is to use larger amounts of fodder resources and smaller amounts of concentrates to prepare the balanced ration because the cost of protein or nutrient supply from fodder resources is generally lower than that from concentrates, especially in developing countries (Makkar, 2016). Also the feed protein use efficiency to milk protein is not impaired in moderate to low milk output systems by decreasing protein-rich concentrate in diets which in turn increases consumption of roughages (Leiber et al., 2015). The use of feeds available on-farm, such as fodder, also helps to reduce nutrient imports, nutrient deposition on the farm and also encourages use of manure as fertilizer. Inclusion of locally available by-products in diets of milk cows in semiarid production systems reduced production costs and GHG emissions by up to $14 \%$ (Alqaisi et al., 2014).

The TMR based on densified straw-based blocks or pellets supplies balanced feeds to animals and increases their productivity. Use of simple technologies, such as chopping forages, increases animal productivity and reduces forage waste. Another example of smart feeding is using fodders when the yields of $\mathrm{CP}$ and/or digestible organic matter per unit of land area from them are maximum. This will maximize the nutrient supply to animals from cultivated fodders in cut-and-carry systems. Portable near-IR spectroscopy is being applied more and more to assess the nutritive value of forages in situ; however, currently its high cost makes its routine use prohibitive. Emphasis should be placed on the need to develop simple and low-cost tools.

The above-discussed approaches could contribute substantially to food security and environment protection.

\section{Pastures, agro-industrial by-products and food loss}

Schader et al. (2015) explored the possibility of using a strategy in which animals are fed only from grassland and food by-products that are human-inedible. Impact of such a strategy on food availability, diet composition and environment was modelled. The study concluded that reducing the proportion of animal feed grown on arable land would have a positive effect on the availability of food and important environmental indicators (reduction in GHG emissions by $18 \%$ and nitrogen surplus by $46 \%$ ). This strategy would clearly have implications on human diets by 2050 . The global availability of livestock products per person would have to decrease by $53 \%$ and availability of meat from pig and poultry would decrease by $91 \%$ and eggs production by $90 \%$ compared with today's consumption levels.

To increase the sustainability of the livestock production systems from the point of view of decreasing emission intensity (Ei) of GHG production, that is GHG production per unit of animal product, a common conclusion is to produce more high-energy concentrate feed on arable land. However, the study by Schader et al. (2015) showed that reducing concentrate feed produced on arable land has considerable potential for attaining sustainable food systems. Furthermore, the strategy ideally complements already existing approaches for enhancing food security like improving the efficiency of food production, distribution and use as well as decreasing consumption of animal products (see below). The above study did not include the role of food loss and waste as animal feed. An analysis by Van Zanten et al. (2016) suggest that using $10 \%$ of the food waste as animal feed, that is $46 \mathrm{~kg}$ annual food waste per person as animal feed along with high digestible co-products, about 0.42 growing pigs per person can be fattened annually. This translates into supply of $14 \mathrm{~g}$ of protein per day per person. Use of food waste should preferentially be used as animal feed. The benefits of reducing food waste to the environment and food security outweigh its utilization as animal feed and every effort should be made to reduce food waste. Potential diversion of food waste for animal feed is however growing, with a number of East Asian states offering working examples of safe food waste recycling, which are based on tight regulation and rendering food waste safe through heat treatment (Salemdeeb et al., 2016).

According to zu Ermgassen et al. (2016) if the EU were to recycle $39.2 \%$ of its food waste as pig feed, this would spare 1.8 million hectares of global farmland, an area half the size of Germany, including more than a quarter of a million hectares of Brazilian soybean. The expansion of soy in the grasslands and forests of Brazil is associated with large GHG emissions and biodiversity loss. In Japan, swill-fed pork is therefore marketed as a premium, low environmental impact product ('Eco-pork') and receives an associated price-premium, which further boosts farm profits. When farmers replace grain- and soybean-based feeds with swill, they reduce demand for these land- and GHG-intensive feeds. The environmental benefits can be substantial.

In some months of a year, availability of vegetable and fruit wastes is also high which can also be converted into valuable resources through silage making. These resources can be used in the dry period when availability of feed is low. Approximately 1.3 Gtonnes of food is lost or wasted globally every year, which is estimated to have enormous environmental, social and economic costs. Also the food loss and waste has an impact on food security, natural resource availability, and local and national economies. A part of these losses can be reduced by converting food loss and waste to animal feed. This would also decrease food-feed 
competition and enlarge the feed resource base, contributing to feed and food security. Valuable nutrients in food wastes can be brought back to the food chain through their use as animal feed. Recently, a study conducted in Bangladesh, jointly with $\mathrm{FAO}$, explored the possibility of using vegetable waste from whole sale vegetable market in Bangladesh. These wastes had $14 \%$ to $15 \% \mathrm{CP}$ and $85 \%$ dry matter digestibility, suggesting it to be a good feed for ruminant livestock. The levels of various hazards such as pesticide, heavy metals and aflatoxin were below the permissible levels (Khan et al., 2017).

The strategy of using human-inedible products as livestock feed makes higher contribution to the net human-edible protein and energy supply and hence to the food security. In our recent analysis (Food and Agricultural Organization (FAO), 2017) on Indian dairy system, based on feeding of crop residues and agro-industrial by-products (grain contribution in the diet of $<2 \%$ ) had the ratio of human-edible protein output (in milk) to human-edible protein input (in feed) (HEPO/HEPI) of 9.9, that is substantial net humanedible protein contribution to the country's food basket. The milk system in India produces a net 4.2 million tonnes of protein (FAO, 2017) which satisfies $100 \%$ daily protein demand of almost 200 million people. If we consider meeting of one-third of the daily protein requirement from animal sources (see below for further discussion), the India dairy sector meets the daily animal protein requirements of around 600 million people. So the net contribution of ruminant systems based on feeding of human-inedible plant components to the food security is enormous. On the other hand, intensive milk production systems, based on use of high grains in the diet, HEPO/HEPI is much lower (1.41 and 1.81 in the UK and USA; Wilkinson, 2011; Council for Agricultural Science and Technology (CAST), 2013), and at times lower than 1 (e.g. 0.60 in Jordan; Alqaisi et al., 2014), meaning that human-edible protein used in the diets is higher than the protein obtained from milk. In other words a net reduction of potential food during conversion from feed into milk. Ertl et al. (2015a) studied net contribution of Austrian dairy farms to human food supply, and the ration of HEPO/HEPI varied from 0.46 to 2.15 , depending on the amount of humanedible components in concentrate in the animal diet. Grassbased dairy production systems contributed substantially to the net food production. Also the substitution of conventionally used concentrate components with by-products from the food processing industry increased the above ratio from 1.60 to 4.27 (Ertl et al., 2015b). Similar pattern is reflected at a country level and for all livestock production systems, including ruminant and monogastric animals Mongolia, which predominantly has a grass-based ruminant production system, has the ratio of 14.6, whereas countries like Germany and USA which predominantly have intensive systems have the ratio of 0.62 and 0.53 , respectively (Food and Agricultural Organization, 2011b). For swine production systems the ratios were: USA $(0.86$ and 0.29$)$, Kenya (0.39), South Korea (0.51) and UK (0.38); and for poultry meat the values were: USA (0.61), Kenya (2.24), South Korea (1.04) and UK (0.48) (Dijkstra et al., 2013). The above synthesis suggests that ruminants reared on food-not feed based diets play an important role as net food producers and have substantial contribution towards enhancing food security, especially in developing countries. It may be argued that the quality of animal source protein and human-edible plant protein differs. Protein quality of animal products is higher by between 1.40 and 1.87, depending on the method used, which can be combined with the HEPO/PEPI concept by multiplying the two ratios (Ertl et al., 2016) to assess net availability of protein to the food security. For meat production systems a wide ranges of HEPO/PEPI have been recorded amongst monogastric and ruminant production systems (Mottet et al., 2017); and ruminant systems have been found to be net protein contributors for human consumption.

Low-input dairy systems existing, for example in India or Kenya are also expected to have other 'wins', especially in social dimension of sustainability. The units of efficiency as 'people lifted out of poverty', 'number of additional children able to go to school', 'improvement in health of children or pregnant women', and 'women empowered' per unit of milk produced are expected to be higher. These units of efficiency are important in the context of developing countries and need to be monitored. Currently, information on these parameters are not available. A study conducted in India (FAO, 2012a) nevertheless, provides evidence of increased women empowerment in the low-input, human-inedible feed ingredient-use systems as a result of implementation of feed-optimization related interventions, in particular balancing of rations at farmers' doorsteps (Bindari and Makkar, 2016).

In the environment dimension of sustainability, units of efficiency, for example 'water use' and 'disruption of nitrogen cycle are also expected to be lower in the low inputs systems compared with the intensive systems, due mainly to the extensive use of locally available feed ingredients and that too human-inedible ones. There is a need to factor-in all these benefits of the low-input systems and to reward them by the market and the society at large. On the other hand, trade-offs could also exist. For example, Ei of milk (GHG emitted per $\mathrm{kg}$ of milk production) was higher in the lowinput systems in India $(2.2 \mathrm{~kg} \mathrm{CO}$-eq/kg milk) and Kenya $(2.0 \mathrm{~kg} \mathrm{CO}$-eq $/ \mathrm{kg}$ milk) that extensively use food-not feed strategy (Garg et al., 2016) than the intensive European production systems ( 0.8 to $1.3 \mathrm{~kg} \mathrm{CO}$-eq/kg milk) (de Vries and de Boer, 2010; Henriksson et al., 2011; 0'Brien et al., 2014). In the former system, the GHG emission is proportionately higher at the rumen level (enteric methane) but lower at the feed production and post-rumen levels (Garg et al., 2016). The role of agro-industrial by-products is vital for reducing GHG emissions and increasing animal productivity in the crop residue based systems because of the higher nutritive value of the former. The use of humaninedible agro-industrial by-products and novel feed resources discussed in this paper may be preferred to create 'win-win' situations. Increase in feed utilization in different production systems has been shown to decrease GHG and use of natural 
resources including arable land for feed-crop production (Herrero et al., 2013, Mottet et al., 2017). Using the approach based on feeding of balanced diets the Ei of milk has been shown to decrease in cows and buffaloes by $30 \%$ and 33\%, respectively (Garg M.R., personal communication) and these decreases were $41.4 \%$ and $46.7 \%$ based on lifetime milk production and GHG emissions (Garg et al., 2016). Most Ei studies are based on Life Cycle Analysis approach of International Standards Organization and International Dairy Federation that takes into account milk production per lactation. However, two publications (Zehetmeier et al., 2014; Garg et al., 2016) report Ei of milk based on lifespan milk and GHG production. The study by Zehetmeier et al. (2014) in German dairy farms showed that a wide range in GHG emissions within region was found from 0.90 to $1.25 \mathrm{~kg}$ $\mathrm{CO}_{2}$-eq/kg FPCM for South-Fleckvieh cows dairy farms and 0.79 to $1.20 \mathrm{~kg} \mathrm{CO}$-eq $/ \mathrm{kg} \mathrm{FPCM}$ for West-Holstein-Friesian cows dairy farms. The study by Garg et al. (2016) focuses on smallholder dairy farms fed mainly human-inedible feed ingredients and $\mathrm{Ei}$ of $1.28 \mathrm{~kg} \mathrm{CO}$-eq/kg for cows is slightly higher than that obtained by Zehetmeier et al. (2014). In the German study number of lactations per cow is between 2.7 and 3 , and in low input systems this number is 5 to 7 . It is also interesting to note that Ei based on lifetime milk production and GHG emissions is $42 \%$ lower than based on one lactation (Garg et al., 2016). As one of the approaches widely recommended to reduce GHG emission is to increase the lifetime of the animals, it may be argued that Ei should also be determined based on lifespan parameters.

\section{Reduction in feed loss}

Food-not feed ingredients such as crop residues and agroindustrial by-products need efficient management. Straws worth millions of dollars are burnt every year in many parts of Asia and Africa, causing environmental problem and soil degradation, in addition to loss of the valuable feed resource. In India $\sim 140$ million tonnes from a total of 500 million tonnes of crop residues are burnt (FAO, 2012c) whereas in China $\sim 37 \%$ of the available crop residues are burnt against $28 \%$ in India (Liu et al., 2008). The crop residue management could include the use of specially designed balers for collection of straw from the field, followed by use of processing technologies for manufacturing balanced complete feed for ruminants. In this respect, the densified straw-based block or pellet technology is an innovative approach for adoption.

Silage making especially using locally available resources, as done in Bangladesh (FAO, 2011a), is also an attractive approach for reducing wastage of forages, especially when their availability is high. The same is true for vegetables and fruits, which can also be converted into valuable feeds (Wadhwa et al., 2015).

Due to lack of proper storage conditions, fungal infestation on feed ingredients is a chronic problem in many developing countries. An increase in both aflatoxin prevalence and level of contamination has been observed between 2005 and 2009, from 32\% to $71 \%$; Streit et al. 2013). The ongoing climate change is also expected to affect the prevalence of mycotoxins. Substantial feed losses inflicted by mycotoxin infestation can be prevented in developing countries by using good agriculture practices. Anaerobic solid-state fermentation technology has also been suggested to decrease toxins and pathogens in by-products (Cao and Li, 2013). Use of mycotoxin-binders also has potential to decrease feed losses. Rodent control on the farm also reduces feed losses, especially of grains.

Some other practical options for decreasing feed waste and losses are the use of sufficiently deep and extended feed troughs, adjusting the feed level in the feeders, and the beak trimming for birds. Following good feed production practices on-farm could also decrease feed losses, for example, for large-scale preparation of TMR, slow delivery of the dusty ingredients in a container used for mixing ingredients, following proper sequence for delivering the feedstuffs and slow mixing of ingredients would reduce feed losses as well as the level of suspended particles in air on the farm. The reduction in food losses and conversion of such losses into animal feed coupled with decrease in feed losses will not only improve food security but also decrease environment footprint of the food-feed systems.

\section{Rationalization of animal product consumption}

The sustainability of livestock systems hinges on two components: supply and consumption of animal products. Addressing sustainability of the feed component is vital for enhancing sustainability of the supply side. On the consumption side, rationalization of animal-derived food consumption is needed. Many people of the developed world suffer from coronary heart diseases, diabetes and obesity, which are attributed to consumption of animal products, among others, beyond the levels recommended for optimal health; whereas in regions such as Africa, the consumption of animal products is very low (e.g. in Burundi $1.7 \mathrm{~g} /$ day per person; $4 \%$ of the total daily protein intake per person against $69 \mathrm{~g} /$ day per person for the USA; $59.5 \%$ of the total daily protein intake per person) (The Food and Agriculture Organization Corporate Statistical Database (FAOSTAT), 2014), which leads to several health-related problems especially among growing children and pregnant women.

Consumption of animal products is not a must for healthy living as long as essential amino acids, vitamins and minerals are met from plant sources. However, literature (Jackson, 2007) suggest that if animal products meet one-third of the daily protein requirement, all essential nutrients are normally met for leading a healthy life. Human nutritionists thus have recommended this level of animal protein consumption (Rand et al., 2003; Marini, 2015). According to World Health Organization/Food and Agricultural Organization/United Nations University (2007) the recommended daily protein consumption is 0.66 to $1 \mathrm{~g} / \mathrm{kg} \mathrm{BW}$. An adult of $60 \mathrm{~kg} \mathrm{BW}$ would require $60 \mathrm{~g}$ of protein per day, and $20 \mathrm{~g}$ of this should come from animal products. The global animal protein production data (FAOSTAT, 2014) show that animal protein availability per capita is $24 \mathrm{~g} /$ day. This analysis shows that 
we are currently producing sufficient animal protein for each one of us. So, if consumption, distribution and affordability of animal products could be addressed, we would need only $33 \%$ more of animal products in 2050 (corresponding to increase in population) than what we are consuming and not $60 \%$ to $70 \%$ as projected. This will have lesser environment burden.

Increase in consumption of animal products in developing countries and in particular African countries, and decrease in developed countries would also contribute to saving of resource-hungry inputs, including feed resources, required for livestock rearing. This effort will also significantly contribute to enhancing sustainability of the livestock sector. From the production side, feeding strategies that rely on use of food-not feed resources would substantially contribute to enhancing food security and make the livestock sector more environmentally benign.

\section{Acknowledgments}

The author is thankful to colleagues for providing useful comments. This paper is an invited contribution following the First Global Farm Platform conference (12 to 15th January, 2016, Bristol, UK). The Global Farm Platform is an international initiative linking research farms around the globe to develop solutions for sustainable ruminant livestock production (www. globalfarmplatform.org).

\section{References}

Alexandratos N and Bruinsma J 2012. World agriculture towards 2030/2050. The 2012 revision. ESA Working Paper No. 12-03, Agricultural Development Economics Division, FAO, Rome, Italy. Retrieved on 3 March 2017 from http:// www.fao.org/docrep/016/ap106e/ap106e.pdf

Alqaisi 0, Hemme T, Latacz-Lohman U and Susenbeth A 2014. Evaluation of food industry by-products as feed in semi-arid dairy farming systems: the case of Jordan. Sustainability Science 9, 366-377.

Bansal N, Tewari R, Gupta JK, Soni R and Soni SK 2011. A novel strain of Aspergillus niger producing a cocktail of hydrolytic depolymerising enzymes for the production of second generation biofuels. BioResources 6, 552-569.

Bindari YR and Makkar HPS 2016. Towards implementation of sustainable animal diets: evidence generation, perspective building and way forward. $C A B$ Reviews 11, 1-27.

Cao Y and Li D 2013. Impact of increased demand for animal protein products in Asian countries: implications on global food security. Animal Frontiers 3, 48-55.

Carter SD and Kim H 2013. Technologies to reduce environmental impact of animal wastes associated with feeding for maximum productivity. Animal Frontiers 3, 42-47.

Council for Agricultural Science and Technology (CAST) 2013. Animal feed vs. human food: challenges and opportunities in sustaining animal agriculture toward 2050. Issue Paper, No. 53, CAST, Washington, DC, USA.

de Vries M and De Boer IJM 2010. Comparing environmental impacts for livestock products: a review of life cycle assessments. Livestock Science 128, $1-11$.

Dijkstra J, France J, Ellis JL, Strathe AB, Kebreab E and Bannink A 2013. Production efficiency of ruminants: feed, nitrogen and methane. In Sustainable animal agriculture (ed. E. Kebreab), pp. 10-25. CAB International, Wallingford, UK. Dubeux JCB, dos Santos Jr. MVF, de Mello ACL, da Cunha MV, de A Ferreira M, dos Santos DC, de A. Lira M and da C Silva M 2015. Forage potential of cacti on drylands. Acta Horticulturae 1067, 181-186.

Dubois B, Tomkins NW, Kinley RD, Bai M, Seymour S, Paul NA and de Nys R 2013. Effect of tropical algae as additives on rumen in vitro gas production and fermentation characteristics. American Journal of Plant Sciences 4, 34-43.
Ertl P, Klocker H, Hoertenhuber S, Knaus W and Zollitsch W 2015a. The net contribution of dairy production to human food supply: the case of Austrian dairy farms. Agricultural Systems 137, 119-125.

Ertl P, Zebel Q, Zollitsch W and Knaus W 2015b. Feeding of by-products completely replaced cereals and pulses in dairy cows, and enhanced edible feed conversion ratio. Journal of Dairy Science 98, 1225-1233.

Ertl P, Knaus W and Zollitsch W 2016. An approach to including protein quality when assessing the net contribution of livestock to human food supply. Animal 10, 1883-1889.

Food and Agricultural Organization 2009. The state of food and agriculture: livestock in the balance. FAO, Rome, Italy. Retrieved on 7 August 2017 from http://www.fao.org/docrep/012/i0680e/i0680e.pdf

Food and Agricultural Organization (FAO) 2011a. Successes and failures with animal nutrition practices and technologies in developing countries. Proceedings of the FAO Electronic Conference, 1-30 September 2010, Rome, Italy. Retrieved on 3 March 2017 from http://www.fao.org/docrep/014/i2270e/i2270e00.pdf

Food and Agricultural Organization 2011b. World livestock-2011: livestock in food security, Rome, Italy Retrieved on 7 August 2017 from http://www.fao.org/ docrep/014/i2373e/i2373e.pdf

Food and Agricultural Organization (FAO) 2012a. Balanced feeding for improving livestock productivity - increase in milk production and nutrient use efficiency and decrease in methane emission. FAO Animal production and Health, paper No. 173, Rome, Italy. Retrieved on 7 August 2017 from http://www.fao.org/docrep/016/i3014e/i3014e00.pdf

Food and Agricultural Organization (FAO) 2012b. Technical Summary. Biofuel co-products as livestock feed-opportunities and challenges (ed. HPS Makkar). Food and Agricultural Organization of the United Nations, Rome, Italy, pp 1-5. Retrieved on 7 August 2017 from http://www.fao.org/docrep/016/i3009e/i3009e.pdf

Food and Agricultural Organization (FAO) 2012c. Crop residue based densified total mixed ration - a user-friendly approach to utilise food crop by-products for ruminant production; by Walli TK, Garg MR, Makkar HPS. FAO Animal Production and Health, paper No. 172, Rome, Italy. Retrieved on 7 August 2017 from http://www.fao.org/docrep/015/i2728e/i2728e00.pdf

Food and Agricultural Organization (FAO) 2017. National Feed Assessment India by Makkar, H.P.S., Otte, J., Anandan, S, Vaid, T, Garg, MR, Bhosale, DT, Ahamad Ali, S, Sahoo, A, Angadi, UB, and Prasad, CS. FAO, Rome, Italy.

The Food and Agriculture Organization Corporate Statistical Database (FAOSTAT) 2014. Food and agriculture data. Retrieved on 7 August 2017 from http://www.fao.org/faostat/en/\#home.

Foidl N, Makkar HPS and Becker K 2001. The potential of Moringa oleifera for agricultural and industrial uses. In The miracle tree: the multiple attributes of moringa (ed. LJ Fuglie), pp 45-76. CTA, Wageningen, the Netherlands.

Gallego AG, Moreira I, de Oliveira Carvalho PL, Perondi D, Pasquetti TJ and Gonçalves LMP 2016. Neutral semi-purified glycerin in growing and finishing pigs feeding. Italian Journal of Animal Science 15, 87-93.

Garg MR, Phondba BT, Sherasia PL and Makkar HPS 2016. Carbon footprint of milk production under smallholder dairying in Anand district of Western India: a cradle-to-farm gate life cycle assessment. Animal Production Science 56, 423-436.

Garg MR, Sherasia PL, Phondba BT and Makkar HPS 2016. Greenhouse gas emission intensity based on lifetime milk production of dairy animals, as affected by ration-balancing program. Animal Production Science, 1-27, http://dx.doi. org/10.1071/AN15586

Gerber PJ, Steinfeld H, Henderson B, Mottet A, Opio C, Dijkman J, Falcucci A and Tempio $G$ 2013. Tackling climate change through livestock - a global assessment of emissions and mitigation opportunities. FAO, Rome, Italy. Retrieved on 7 August 2017 from http://www.fao.org/3/i3437e.pdf

Henriksson M, Flysjö A, Cederberg C and Swensson C 2011. Variation in carbon footprint of milk due to management differences between Swedish dairy farms. Animal 5, 1474-1484.

Herrero $M$, Havlík $P$, Valin $H$, Notenbaert $A$, Rufino MC, Thornton PK, Blümmel $M$, Weiss $F$, Grace $D$ and Obersteiner $M$ 2013. Biomass use, production, feed efficiencies, and greenhouse gas emissions from global livestock systems. Proceedings of the National Academy of Sciences USA 110, 20888-20893.

Jackson AA 2007. Protein. In Essentials of human nutrition, 3rd ed. eds. J Mann and S. Truswell), pp 53-72, Oxford University Press, Oxford, UK.

Jankowski J, Juskiewicz J, Gulewicz K, Lecewicz A, Slominski BA and Zdunczyk Z 2009. The effect of diets containing soybean meal, soybean protein concentrate, and soybean protein isolate of different oligosaccharide content on 
growth performance and gut function of young turkeys. Poultry Science 88 , 2132-2140.

Khan SH, Das KS, Amanullah NG, Dharmapuri SM and Makkar HPS 2017. Quantification, chemical composition and nutritional values of food wastes. Journal of Environment Management (Submitted).

Latif S, Kumar V, Stadtlander T, Makkar HPS and Becker K 2015. Nutritional and biochemical studies on feeding of hydrolysed and unhydrolysed detoxified Jatropha curcas protein isolate in common carp fingerlings. Aquaculture Research 46, 1-15.

Leiber F, Dorn K, Probst JK, Lsensee A, Ackermann N, Kuhn A and Neff AS 2015. Concentrate reduction and sequential roughage offer to dairy cows: effects on milk protein yield, protein efficiency and milk quality. Journal of Dairy Research 82, 272-278.

Li X, Norman HC, Kinley RD, Laurence M, Wilmot M, Bender H, de Nys R and Tomkins N 2016. Asparagopsis taxiformis decreases enteric methane production from sheep. Animal Production Science, https://doi.org/10.1071/AN15883

Liu H, Jiang GM, Zhuang HY and Wang KJ 2008. Distribution, utilization structure and potential of biomass resources in rural China: with special references of crop residues. Renewable and Sustainable Energy Reviews 12, 1402-1418.

Makkar HPS 2014. Biofuel co-products as livestock feed - opportunities and challenges, technical summary. FAO, Rome, Italy. Retrieved on 7 August 2017 from http://www.fao.org/docrep/019/i3650e/i3650e.pdf

Makkar HPS 2016. Smart livestock feeding strategies for harvesting triple gain the desired outcomes in planet, people and profit dimensions: a developing country perspective. Animal Production Science 56, 519-534.

Makkar HPS and Ankers P 2014. Towards sustainable animal diets: a surveybased study. Animal Feed Science and Technology 198, 309-322.

Makkar HPS. and Becker K 1997. Nutrients and antiquality factors in different morphological parts of the Moringa oleifera tree. Journal of Agriculture Science 128, 311-322.

Makkar HPS, Tran G, Heuzé V and Ankers P 2014. State-of-the-art on use of insects as animal feed. Animal Feed Science and Technology 197, $1-33$.

Makkar HPS, Tran G, Heuzé V, Giger-Reverdin S, Lessire M, Lebas F and Ankers P 2016. Seaweeds for livestock diets: a review. Animal Feed Science and Technology 212, 1-17.

Marini JC 2015. Protein requirements: are we ready for new recommendations? Journal of Nutrition 145, 5-6.

McDonnell P, Figat $S$ and $O^{\prime}$ Doherty JV 2010. The effect of dietary laminarin and fucoidan in the diet of the weanling piglet on performance, selected faecal microbial populations and volatile fatty acid concentrations. Animal 4 , 579-585.

Medhi D 2011. Effects of enzyme supplemented diet on finishing crossbred pigs at different levels of silk worm pupae meal in diet. Indian Journal of Field Veterinarians 7, 24-26.

Mottet A. de Hann C, Falcucci A, Tempio G, Opio C and Gerber P 2017. Livestock: on our plates or eating at our table? A new analysis of the feed/ food debate. Global Food Security 14, 1-104.

O'Brien D, Brennan P, Humphreys J, Ruane E and Shalloo L 2014. An appraisal of carbon footprint of milk from commercial grass-based dairy farms in Ireland according to a certified life cycle assessment methodology. International Journal of Life Cycle Assessment 19, 1469-1481.

Oliveira L, Madrid J, Ramis G, Martínez S, Orengo J, Villodre C, Valera L, López MJ, Pallarés FJ, Quereda JJ, Mendonça L and Hernández F 2014. Adding crude glycerin to nursery pig diet: Effect on nutrient digestibility, metabolic status, intestinal morphology and intestinal cytokine expression. Livestock Science 167, 227-235.

Opheim M, Strube ML, Sterten H, Øverland M and Kjos NP 2016. Atlantic salmon (Salmo salar) protein hydrolysate in diets for weaning piglets - effect on growth performance, intestinal morphometry and microbiota composition. Archives Animal Nutrition 70, 44-56.
Osorto WA, Lara PE and Magana M 2007. A Mulberry (Morus alba), fresh or in the form of meal, in growing and fattening pigs. Cuban Journal of Agricultural Science 41, 59-63.

Rahman KHA, Yusof SJHM and Zakaria Z 2016. Bioproteins production from palm oil agro-industrial wastes by Aspergillus terreus UniMAP AA-1. Pertanika Journal of Tropical Agriculture Science 39, 29-39.

Rand WM, Pellett PL and Young VR 2003. Meta-analysis of nitrogen balance studies for estimating protein requirements in healthy adults. American Journal of Clinical Nutrition 77, 109-127.

Robinson T and Makkar HPS 2012. Demand growth for animal-source foods: implications for livestock feed production. In Conducting national feed assessments. FAO animal production and health manual No. 15. (eds MB Coughenour and HPS Makkar) pp 59-65, FAO, Rome, Italy. Retrieved on 7 August 2017 from http://www.fao.org/docrep/016/i3043e/i3043e.pdf

Salemdeeb R, zu Ermgassen EKHJ, Kim MH, Balmford A and Al-Tabbaa A 2016. Environmental and health impacts of using food waste as animal feed: a comparative analysis of food waste management options. Journal of Cleaner Production 140, 871-880.

Schader C, Müller A, El-Hage Scialabba N, Hecht J, Isensee A, Erb K-H, Smith P, Makkar HPS, Klocke P, Leiber F, Schwegler P, Stolze M and Niggli U 2015. Impacts of feeding less food-competing feedstuffs to livestock on global food system sustainability. Journal of the Royal Society Interface 12, pp 1-12.

Shreck AL, Nuttelman BL, Griffin WA, Erickson GE, Klopfenstein TJ and Cecava MJ 2012. Chemical treatment of low-quality forages to replace corn in cattle finishing diets. Nebraska Beef Cattle Report, Lincoln, Canada, pp. 106-107.

Streit E, Naehrer K, Rodrigues I and Schatzmayra G 2013. Mycotoxin occurrence in feed and feed raw materials worldwide: long-term analysis with special focus on Europe and Asia. Journal of the Science of Food and Agriculture 93, 2892-2899.

Swiatkiewicz S, Swiatkiewicz M, Arczewska-Wlosek A and Jozefiak D 2016. Efficacy of feed enzymes in pig and poultry diets containing distillers dried grains with solubles: a review. Journal of Animal Physiology Animal Nutrition 100, 15-26.

Thieme 0 and Makkar HPS 2017. Utilization of loss and waste during the food production cycle as livestock feed. Animal Production Science 57, 601-607.

Tran G, Heuzé V and Makkar HPS 2015. Insects in fish diets. Animal Frontiers 5 , 37-44.

Vancov T and Mclntosh S 2011. Alkali pretreatment of cereal crop residues for second-generation biofuels. Energy Fuels 25, 2754-2763.

Van Zanten HHE, Meerburg BG, Bikker P, Herrero M and de Boer IJM 2016. Opinion paper: the role of livestock in a sustainable diet: a land use perspective. Animal 10, 547-549.

Wadhwa M, Bakshi MPS and Makkar HPS 2015. Waste to worth: fruit wastes and by-products as animal feed. CAB Reviews 10, pp 1-26.

World Health Organization/Food and Agricultural Organization/United Nations University 2007. Protein and amino acid requirements in human nutrition. Report of a joint FAO/WHO/UNU expert consultation. WHO Technical Report Series No. 935, World Health Organization United Nations University, Geneva, Switzerland, p. 265.

Wilkinson JM 2011. Redefining efficiency of feed use by livestock. Animal 5, 1014-1022.

Zehetmeier M, Hoffmann H, Sauer J, Hofmann G, Dorfner G and O'Brien D 2014. A dominance analysis of greenhouse gas emissions, beef output and land use of German dairy farms. Agricultural Systems 129, 55-67.

Zhang HY, Piao XS, Li P, Yi JQ, Zhang Q, Li QY, Liu JD and Wang GQ 2013. Effects of single cell protein replacing fish meal in diet on growth performance, nutrient digestibility and intestinal morphology in weaned pigs. Asian-Australasian Journal of Animal Science 26, 1320-1328.

zu Ermgassen EKHJ, Phalan B, Green RE and Balmford A 2016. Reducing the land use of EU pork production: where there's swill, there's a way. Food Policy $58,35-48$. 